ISSN 1112-9867

Available online at http://www.jfas.info

\title{
TOWARDS AN ISLAMIC SPIRITUALITY MODEL IN INCREASING ACADEMIC PERFORMANCE OF ACCOUNTING STUDENTS
}

\author{
G. Rosliza*, A. A. Inayah, T. Emiza, C. A. Merani, and Y. Yusliena \\ Faculty of AccountancyUniversiti Teknologi MARA Terengganu, 23000 \\ Dungun, Terengganu, Malaysia
}

Published online: 17 October 2017

\begin{abstract}
Ideally, a good education system should be able to develop the potential of students in a holistic and integrated manner. In many academic literatures, there is someevidence proving that the elements of spirituality are fundamental to students' personal development that could produce well-balanced students. Interestingly, spirituality has been found to havea positive effect on academic performance of students because highly spiritual students are associated with high learning motivation. Thus, the objective of this study is to propose a teaching and learning model which incorporates Islamic spirituality elements in student activities that could increase their academic performance. The study suggests a few approaches to improve student religiosity that could be implemented by the Faculty, namely Halaqah, Islamic Motivation Talk, and Islamic RitualProgramme.
\end{abstract}

Keywords: spirituality;Islamic spirituality; academic performance; learning motivation.

Author Correspondence, e-mail: rosliza@tganu.uitm.edu.my

doi: http://dx.doi.org/10.4314/jfas.v9i5s.65 


\section{INTRODUCTION}

\subsection{Objectiveof the Study}

Excellent academic achievement is perceived as an ultimate goal of every student notwithstanding the level of education. All education systems worldwide ideally struggle towards developing individuals in a holistic and integrated manner, producing individuals who are intellectually, spiritually, emotionally, and physically well-balanced. Recently, the role of spirituality in academic success is recognised. A study has found that spirituality serves as a source of inspiration for students to focus on study and work hard to excel academically [1]. Meanwhile, other studies have also revealed that spirituality has a positive impact upon students' academic performance and those who arecommitted to spiritual activities show excellent academic performance [2][3].In the interim, there is also some evidence which stating that the lack of spirituality among students has caused many unfavourable academic issues, such as the lack of interest in studies, absenteeism, lack of self-worth, lack of self-interest, poor academic performance, and involvement in negative activities. Undeniably, these problems would significantly lead to poor academic performance.

Therefore, the focus of this study is to propose a teaching and learning model to the higher education institution which incorporates Islamic spirituality in student activities needed to provide positive impacts on the students' academic performance. The study has suggested a few methods that could be implemented by the Faculty to improve student religiousityby encouraging more involvement in the religious activities, namelyHalaqahProgramme, Islamic Motivation Talk, and Islamic Ritual Programme.

\subsection{Problem Statement}

In Malaysia, spiritual deficiency in the current education practices has provideda few opportunities for students to discover the meaning and wholeness in this life. This normally leads to the absence of a holistic objective in studies, which could cause unfavourable attitude problems, for instance, class absenteeism. This study believes that the problem of student absenteeism is associated with the lack of learning motivation that results in poor academic performance. As stated in previous literatures, there is a significant strong positive relationship found between class attendance and academic performance [4][5]. 
In Islamic teaching, among the methods which can be implemented to improve learning motivation isthe enhancement of students' spiritual connection with Allah SWT.It includes performing the five daily obligatory prayers (Solat), reciting the Qur'an, performing the Qiyam al-lail(night prayers), and making tawakkul(reliance) on Allah [6]. Struggling to keep motivated is a challenge among students, otherwise, they would continue to distress, be poor in academic performance, or even withdraw from university. Spirituality could be one of the solutions to help students to deal with the challenges as it has been found that spiritual well-being and academic performance havea positive association [7].Moreover, the result of a study has revealed that students with a high level of religiosity possess a high level of academic performance [8].

\section{LITERATURE REVIEW}

\subsection{Definition of Spirituality and Islamic Spirituality}

In general terms, spirituality is the aspect of humanity that refers to the way that individuals seek and express meaning and purposeof life [9].[10]havedefinedspirituality as"any experience that is thought to bring the experiencer into contact with the Divine, not just any experience that feels meaningful'. Meanwhile, [11]has suggested thatspirituality represents a necessary essence of life that energises both thoughts and actions of man.

In Islam, spirituality is defined asthe adherence to the set of Islamic rituals and codes, which results in one's striving to become closer to the God (Allah SWT). With it, Muslims are able to find personal worth and actualisation in life[12].Similarly, [13] has related the definition of Islamic spirituality with the purpose of life when arguing that, since a Muslim's purpose of life is to worship Allah SWT, spirituality in this sense is linking the actions of individuals to the purpose of their lives. More importantly, [14]has defined Islamic spirituality as the presence of a relationship with the God (Allah SWT) that affects the individual's self-worth, sense of meaning, and connectedness with others and nature.

\subsection{Impact of Spirituality on Academic Performance}

Prior studies in spirituality havesuggested that spirituality has a positive impact upon the academic performance of students and those who are committed to spiritual activities show excellent academic performance [2][15][3]. Moreover, [7]have also found a positive 
correlation between spiritual well-being and academic achievement.

Even though there are many other factors that influence academic performance, such as self-motivation, teaching and learning styles, parents' education level, and family income, it was found that there is a significant correlation between the spiritual practices of students and their academic achievement [6]. In the meantime, it was also reported that participating in spiritual programmes and spiritual beliefs is positively related to academic performance [16], [2]. Hence, it is understood that adopting some Islamic practices in learning activities has given a positive impact to the students, too. Some examples of such spiritual practices are reciting prayers or duá prior to study, putting hope only on Allah SWT (concept of Tawakkal to Allah SWT), always feeling motivated, and always being grateful to Allah SWT when succeeding in their studies.

In addition, some research studies have also found that highly spiritual students have many positive attitudes, which are truly important in their lives. Students who are committed to their religion are well-behaved, have high self-confidence, good emotional health, and high self-control which result in higher academic achievement. For instance, when confronted with stressful circumstances, they are likely to be using positive coping strategies which enable them to decrease stress, change perspectives, provide a sense of meaning and purpose oflife, and provide social support and inspiration. [17][18][19][20].

Spirituality is commonly associated with some religious involvement, such as charity work and other religious activities. A high level of religious involvement enables students to gain greater satisfaction, feel good about life, and be at peace. A religiously involved person hasa tendency to excel in school since religiosity has a positive impact on academic achievement. It is believed that, as the religiosity level increases, academic achievement will increase accordingly. Highly spiritual people feel more positive about their academic experience since they believe that God provides them with wisdom and resources needed to be successful [15][21][22][23].Meanwhile, a significant relationship between spiritual well-being and college adjustment in terms of academic, social, and emotional among the students is found in a study by [24]. The three elements aforementioned are inter-related to each other and can affect one another. Moreover, [25]have stated that spirituality allows individuals to find meaning in life, relate to a supreme power, experience joy and hope, and develop 
relationships.In a study conducted by [26], it was unveiled that both emotional and spiritual well-beings play a crucial role in developing the students' potentials since the process of education is not merely empowering the academic, but also balancing the growth of students' morality and personality. Additionally, [27]has also found that there is a significant relationship between psychological well-being and Christian spiritual well-being at a small Christian Liberal Arts College in the Urban Midwest.

\subsection{Incorporation of Spirituality in Student Activities}

The trend of the incorporation of spirituality into the current education has taken place globally due to the awareness of its role in achieving the concept of holistic learning. In the holistic learning approach, the mind and spirituality can no longer be ignored as theconnection between the two is vital for the student personal development. Thus, a more effective teaching pedagogy which incorporatesspirituality into the process of teaching and learning should be developed by educators that can help students to develop a cohesive, meaningful, and holistic worldview.Besideas, the educators should also inform and remind the students that spirituality is a part of everyday life rather than being confined to temples, mosques, churches, or nature, thus, giving the educators opportunities to incorporate spirituality in the academic arena.

For many higher-education students, their most basic understanding of life has been formed as a result of religious nurture at their home. As such, when students leave their home and enter the formative years of the early adulthood phase, their time in a higher-education institution becomes fundamental in developing their identity and spiritual beliefs and helping them to give the meaning and purpose oftheir lives. [28]hasclaimed that new students regularly place their significant personal emphasis on matters related to spirituality and have high expectations for the role that their university should play forstudent emotional and spiritual development. [29] hasproposed that the educators must be aware of the increasing student expectation that higher-education institutions will guide studentsin their spiritual development.

The task to incorporate spirituality into class discussions and programmes is not an easy task for both Faculty and student development personnel of the higher-education institutions[29]. The primary barriers to integrating spirituality include the definitional complexity of the term 
spirituality, the dominance of secular and materialistic values, the lack of models, and the problem of the Faculty preparedness and accountability. It is difficult to know where to begin the incorporationof spirituality into their curriculum, which results in the out-of-class discussions. Consequently, the commonapproach engaged by many higher-education institutions is by incorporating spirituality into some student-organised events, such as forums and discussions which provide valuable spiritual and educational experiences to them[30].

Realising the high interest on the incorporation of spirituality in life by students and the great effect it has on the student academic performance and psychological well-being, many universities around the globehave fostered an environment that is conducive to the spiritual development of students. For example, the University of Nottingham in the U.K. hasorganised many spiritual activities for Muslim students, namely Brothers' Tajweed Class, Learn the Tafseer in Arabic, and Memorise the Qur'an.Meanwhile, the University of Wisconsin-Milwaukee in the U.S.has focused on the student spiritual development through the involvement and participation in high-impact activities, such as Inter-faith Dialogue, charitable involvement, and reflection/meditation exercises. Similarly,DePaul University, the greatest Chatolic higher-education institution in the U.S.,has supported and enrichedthe campus life of Muslim students by providing them a variety of spiritual programmes, such as weekly Friday prayers (Salat al-Jumu'ah), study circles (Halaqah), Iftar dinners during Ramadhan, and campus celebration of Eid-ul-Fitr and Eid-ul-Adha. At Universiti Brunei Darussalam, students are nurtured as Professional Muslims and comprehensive individuals (InsanSyumul) through religious programmes, such as the Qur'anic Teaching Programme and the celebration of important days in Islam,such as the Prophet Muhammad's Birthday, the Day of Revelation of the Qur'an, the first day of Islamic Calendar (TaqwimHijri), and many other important events of Islam.

\subsection{ISLAMIC SPIRITUALITY MODEL}

The Islamic Spirituality Model suggested by this research study is shown in the Fig. 1 as follows: 


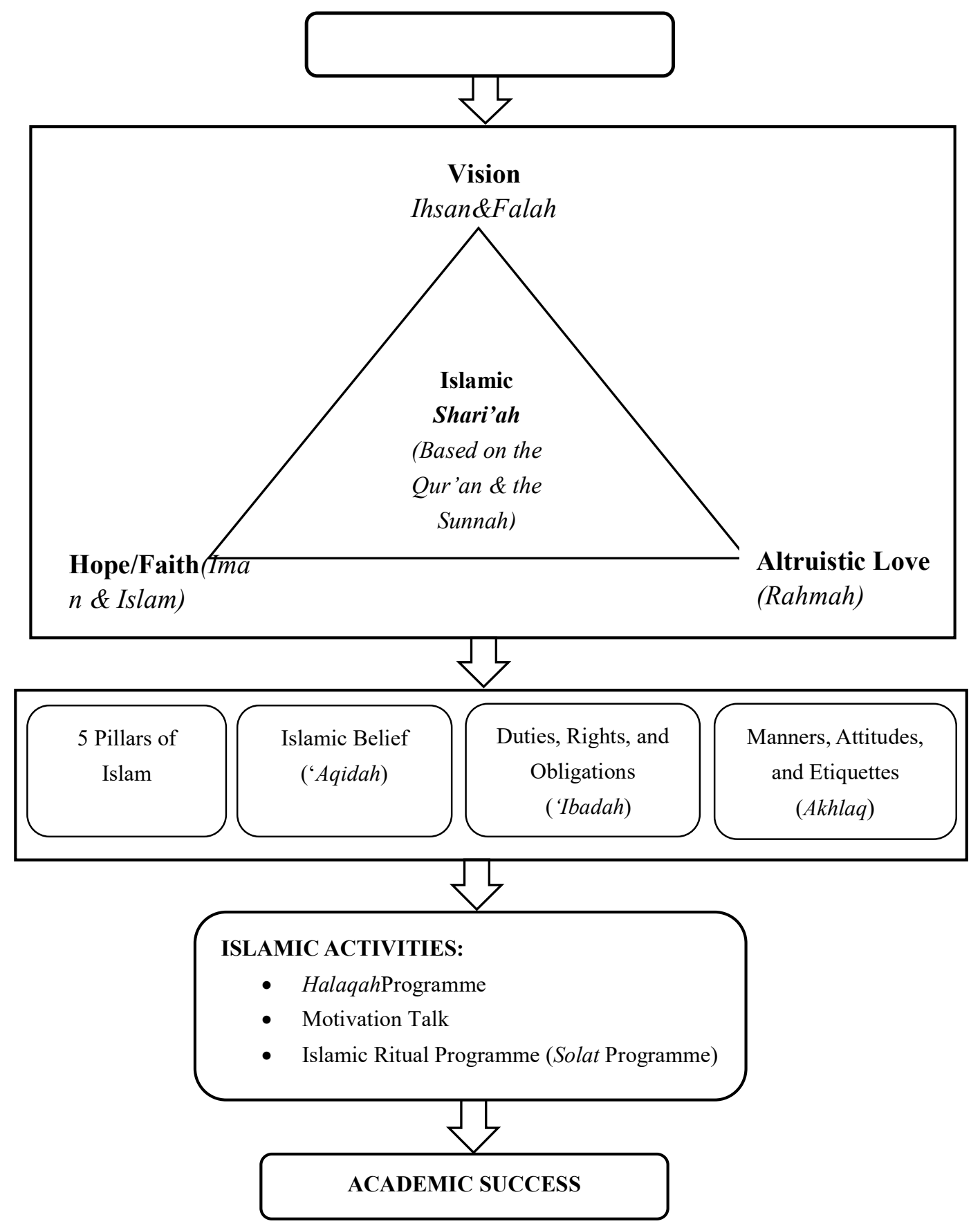

Fig.1. Islamic spirituality model

The foundation ofIslamic spirituality is the adherence to the Islamic Shari'ah, which is based on two Islamic primary sources, namely the Qur'anand the Sunnah (the tradition of Prophet Muhammad PBUH). These two sources explicitly incorporate the conscious reflection and 
contemplation of the God (Allah SWT) and faith (Iman) as the basesfor all deeds performed by every Muslim. True individual Muslims always strive to become closer to the God (Allah SWT) to find personal worth and life actualisation. As such, the adherence to correct vision in life using the concept of Ihsan(the sense of responsibility to the God), Falah(success),Iman(faith), and Rahmah(altruistic love) are the bases of Muslim actions, either in the context of worldly life or life in the hereafter. In relation to Muslim students, striving hard in studiesto achieve success (Falah)is a good deed and stands a chance to receive pleasure from the God (Allah SWT).

The model hereby aims at producing ethical and moral responsibility based on spiritual values, such as trust, patience, compassion, forgiveness, and so on. Thus, the study has suggestedHalaqahProgramme, Islamic Motivational Talk, and Islamic Ritual Programme tobe integrated into student activities. The contents of the programmes are based mainly on the five Pillars of Islam ('aqidah), manners and attitudes (akhlaq), and Muslim's duties, rights, and obligations ( 'ibadah), of which are expected to provide the input that will inspire students to be more meaningful learners and ultimately successful in their academic.Halaqahis a weekly outside-classroom meeting led by a facilitator with the aim to find effective ways to inculcate the Islamic value system in students in small groups. It is intensive and spiritually focused to facilitatecomprehensive character development of the members. Motivationaltalks organised by the Faculty integrating Islamic values are then led by experts in Islamic areas. The aim is to exposed students continuously with Islamic knowledge, which is vital for their spiritual development. For Islamic Ritual Programme,the Faculty focuses on the study of daily prayers (Solat) programme, which is considered the most important act of worship for Muslims. In addition to that, the Faculty can organise other activities, such as Qur'anic studies, RamadhanTazkirah, and Sadaqahprogramme.

\section{CONCLUSION}

A good-quality education is meant to teach moral values and spiritual elements to produce students who are morally and academically excellent. To be excellent, one should possess some good spirituality elements, whichare viewed by many researchers as the fundamental 
elements for a person's well-being that could lead to the success in life. In general, a highly spiritual person is a well-adjusted person that is normally able to face life challenges easily. Thus, this research has aimed to contribute to a quality education by creating a more holistic and transformative educational process with the intention of producing successful and well-balanced students by incorporating Islamic spirituality elements inside the students activities.

\section{ACKNOWLEDGEMENT}

The research for this paper is financially supported by UniversitiTeknologi MARA, Malaysia, under the Academic and Research Assimilation (ARAS) Granttitled "Towards an Islamic Spiritual Model in Increasing Academic Performance of Accounting Students”. We would like to thank UniversitiTeknologi MARA for supporting and allowing us to work on this research.

\section{REFERENCES}

[1]William O B, Isaac O O. Student spirituality and academic performance: A case study of Kwame Nkrumah University of Science and Technology (KNUST) Ghana. British Journal of Education, Society \&Behavioural Science, 2016, 17(4):1-13

[2]Walker K L, Dixon V. Spirituality and academic performance among African American college students. Journal of Black Psychology., 2002,28(2):107-121

[3]Fukofuka S. The impact of spirituality on academic performance. International Forum, $2007,10(2): 35-47$

[4] Lukkerinen A, Koivukangas P, and Seppala T. Relationship between class attendance and student performance. Procedia-Social and Behavioural Sciences., 2016, 228, 341-347

[5]Aden AA, Yahye Z A, and Dahir A M. The effect of student's attendance on academic

performance: A case study at SIMAD University Mogadishu. Journal of Academic Research International., 2013, 4(6):409-417

[6]Salasiah H H, Zainab I, Rosmawati M R, and Ermy A R. Methods of increasing learning motivation among students. Procedia Social and Behavioral Sciences, 2010, 18, 138-147 
[7]Mariani O,NurFadhilah A F. Spiritual well-being and academic achievement among university students. International Counseling Conference and Work,2014, 13-15

[8]Zubairu U M, Sakariyau O B. The Relationship between religiosity and academic performance amongst accounting students. International Journal of Evaluation and Research in Education., 2016, 5(2):165-173

[9]Pulchaski C, Ferrell B, Virani R, Otis-Green S, Baird P....Sulmasy D. Improving the quality of spiritual care as a dimension of palliative care: The report of the consensus conference. Journal of Palliative Medicine, 2009, 12 (10):885-904

[10]Beauregard M, O’LearyD. The Spiritual Brain. New York: Harper Collins, 2009

[11] Taylor E J. Spiritual Care: Upper Sadder River, NJ: Prentice Hall, 2002

[12]Khodayarifard M, Ghobari B B, Shokoohi Y M, Behpajoh A, Afrooz G A, Abedini Y, and Parknejadi M. Developing a religiosity scale for Iranian college students. Journal of Psychology and Education, 2008, 38(3):23-115

[13] Khan A. Islam and spirituality, 2009

[14]Nasr S H. Islamic spirituality. London: Routledge and Keegan Paul, 1987

[15]Bonderud K, Fleischer M. Study reveals influences of college on students' spiritual and religious development, Spritual in Hgiher Education, 2004

[16]Hodge D R. Releasing students from class for spiritual instruction: Does it hinder academic performance? Children and Schools,2007, 29(3):161-171

[17]Jeynes W H. A meta-analysis of the effect of attending religious schools and religiousity on black and hispanic academic achievement. Education and Urban Society., 2002, 35(1):27-49

[18]Regnerus M D. The influence of religion upon the academic performance of youth in disadvantage communities. Baylor Institut for Studies of Religion Report, 2006.

[19]Steward R J, Jo H. Does spirituality influence academic achievement and psychological adjustment of African American urban adolescents?, Research Report, 1998, 1-16

[20]Cox C J. The relationship between spirituality, stress, and academic performance, Master Thesis, Green State University, 2011.

[21]Williams T R, Davis L E, Miller C J, Saunders J, and Williams J H. Friends, families, and 
neighborhoods: Understanding academic outcomes of African American youth. Urban Education,2002, 37(3):408-432

[22]Antrop-González R, Vélez W, and Garrett T. Religion and high academic achievement in Puerto Rican High School students. Journal Religion and Education. 2007, 34(1):63-75

[23]Elder G H, Conger R D. Children of the land. Chicago: University of Chicago Press,2000. [24]Norwati M, Nursyahidah K. Spiritual well-being of INSTED, IIUM Students' and its relationship with college adjustment. Procedia of Social and Behavioral Sciences, 2012, 69, $1314-1323$

[25]Isaia D, Parker V, and Murrow E.Spiritual well-being among older adults. Journal of Gerontological Nursing, 1999,25(8):15-21

[26]Aminuddin H. Emotional and spiritual intelligences as a basis for evaluating the national philosophy of education achievement. Research Journal of International Studies,2009,12, 60-63

[27]Richter R J. Correlation of psychological well-being and Christian spiritual well-being at a small Christian Liberal Arts College in the urban Midwest, 2001, In $1^{\text {st }}$ Annual Undergraduate Research Symposium, pp. 1-21

[28]Kuh G D, Gonyea R M. Spirituality, liberal learning, and college student engagement. Liberal Education,2006, 92(1):40-47

[29]Shahjahan R. The role of spirituality in the anti-oppressive higher-education classroom. Teaching in Higher Education, 2009. 14(2):121-131

[30]Lindholm J A. Spirituality in the academy: Reintegrating our lives and the lives of our students. About Campus, 2007, 12(4):10-17

\section{How to cite this article:}

Rosliza G, Inayah A A, Emiza T, Merani C A, Yusliena Y. Towardsan Islamic spirituality model in increasing academic performance of accounting students. J. Fundam. Appl. Sci., 2017, 9(5S), 921-931. 